This is an electronic reprint of the original article. This reprint may differ from the original in pagination and typographic detail.

\author{
Author(s): Jääskelä, Päivikki; Poikkeus, Anna-Maija; Vasalampi, Kati; Valleala, Ulla Maija; Rasku- \\ Puttonen, Helena
}

Title: $\quad$ Assessing agency of university students : validation of the AUS Scale

Year: $\quad 2017$

Version:

Please cite the original version:

Jääskelä, P., Poikkeus, A.-M., Vasalampi, K., Valleala, U. M., \& Rasku-Puttonen, H. (2017). Assessing agency of university students : validation of the AUS Scale. Studies in Higher Education, 42(11), 2061-2079.

https://doi.org/10.1080/03075079.2015.1130693

All material supplied via JYX is protected by copyright and other intellectual property rights, and duplication or sale of all or part of any of the repository collections is not permitted, except that material may be duplicated by you for your research use or educational purposes in electronic or print form. You must obtain permission for any other use. Electronic or print copies may not be offered, whether for sale or otherwise to anyone who is not an authorised user. 
Higher education, 2016

DOI: $10.1080 / 03075079.2015 .1130693$

\title{
Assessing agency of university students: Validation of the AUS Scale
}

\author{
Päivikki Jääskelä ${ }^{\mathrm{a}}$, Anna-Maija Poikkeus ${ }^{\mathrm{a}}$, Kati Vasalampi ${ }^{\mathrm{a}}$, Ulla Maija Valleala ${ }^{\mathrm{a}}$, and \\ Helena Rasku-Puttonen ${ }^{\mathrm{a}}$ \\ ${ }^{a}$ University of Jyvaskyla, Department of Teacher Education, Jyvaskyla, Finland
}

\begin{abstract}
Fostering agency as a core component of professionalism is seen as a critical task of higher education. However, the tools for assessing university students' agency, and the pedagogical and relational resources needed for its development, are lacking. The present study describes the theoretical foundations and factor structure of the newly developed Agency of University Students (AUS) Scale, which assesses students' course-specific agency. In the factor analysis, ten factors emerged. Four of these - Interest and motivation, Self-efficacy, Competence beliefs and Participation activity - are seen to represent individual resources of agency. The other four factors - Equal treatment, Teacher support, Peer support and Trust - represent relational sources of agency. Finally, Opportunities to influence, and Opportunities to make choices represent contextual sources of agency. The psychometric properties and uses of the scale are discussed.
\end{abstract}

Keywords: agency, assessment, university students, scale development

\section{Introduction}

Preparing students for competencies needed in the modern work market is a central challenge for higher education. The functions set by the Humboldian ideal of the university as a place of civilization are not always compatible with the newer functions (see e.g. Michelsena 2011; Santiago, Carvalho, and Relva 2008), and the demands of modern professional work life (e.g. Framework of Qualifications for the European Higher Education Area 2005; OECD 2013). Recent studies (e.g. Littleton, Taylor, and Eteläpelto 2012; Paloniemi and Collin 2012; Tynjälä 2010) emphasise agency as a core component of professionalism, with increasing call for creativity, collaboration and dynamism. Agency is also seen as a way of coping with uncertainty and changes in working life, thus, playing a key role in lifelong learning ( $\mathrm{Su}$ 2011).

Based on their review of the higher education literature on the development of professional identities, Trede, Macklin and Bridges (2012) conclude that universities focus on teaching theoretical and formal knowledge but do not address the increasing pressure to prepare students for the world of work. They argue that professional identity development requires students' active engagement and agency along with support for it from educators. In

\footnotetext{
${ }^{1}$ Corresponding author. E-mail: paivikki.jaaskela@jyu.fi
} 
line with this, Barnett (2009) stresses that higher education should not only address knowledge and/or skills but also capabilities for engaging purposively with the changing and complex world. The existing literature suggests that higher education programmes do not typically or systematically support students' conscious agency building but, rather, focus on content-based knowledge construction. Furthermore, Trede et al. (2012) point out that despite the acknowledged merits of collective learning, professional development in higher education is mostly concerned with individual learners and that aspects of power relations and external influences have largely been ignored. We suggest that students' agency is constructed and actualised in learning situations that offer opportunities for participation and influence, and for recognising one's individual strengths, personal interests and goals, and provide resources for the development of an identity as a learner and a future professional expert.

The concept of agency has been widely used in social sciences (Giddens 1984; Archer 2003), philosophy (Ci 2011), adult education and learning (e.g. Billett 2008; Edwards 2005; Eteläpelto et al. 2014). It also has roots in psychology and social cognitive theory (Bandura 1989). Moreover, agency has become a research interest of childhood (e.g. Kylie 2011), aging (e.g. Jolanki 2009; Jyrkämä 2008), life-course (e.g. Biesta and Tedder 2007; Hitlin and Elder 2007) and gender (e.g. Liimakka 2011) research. In recent years, agency has also become an explicit focus of conceptual analyses of work-related learning research (see Eteläpelto et al. 2013). Despite the perceived importance of agency in various stages of life span, studies on agency in the higher education context are rare, and they mostly employ a qualitative approach and target very small groups of university students, typically in teacher education (e.g. Lipponen and Kumpulainen 2011; Eteläpelto et al. 2005). Little is known about the experiences and resources of agency among university students across different disciplines and the extent to which faculties recognise and pay attention to their students' agency experiences during courses. The goal of the present study was to develop an instrument for assessing agency in higher education in order to provide information about the resources and pedagogical choices supporting students' agency building during their studies.

Several strands of higher education research are related to agency, but they typically focus on unitary dimensions and individual factors, such as students' experiences of self-efficacy (e.g. van Dinther, Dochy and Segers 2011), autonomy (e.g. Bonneville-Roussy, Vallerand and Bouffard 2013), interest and future goals (e.g. Mikkonen, Ruohoniemi, and LindblomYlänne 2013), achievement goals (e.g. Mattern 2005) or intrinsic motivation (e.g. Busse 2013). Interactional and contextual factors influencing the construction of agency among higher education students have been examined in studies on teacher-student relationships 
(e.g. Cornelius-White 2007) and student-centred learning (e.g. McCabea and O'Connorb 2014; Elen et al. 2007) even though the concept itself is typically not explicitly used. In the present study, a self-report questionnaire was developed to assess university students' agency within a framework which takes into account the interplay of individual and socio-cultural, interactional and contextual aspects of learning (Eteläpelto et al. 2013; Kahn, Qualter, and Young 2012). The pilot questionnaire was developed during academic year 2010-2011 and was modified and further developed in academic year 2013 in the context of a universitylevel project "Interactive Teaching and Learning" implemented at the University of Jyväskylä, Finland. The aim was to offer a tool for university teachers of different disciplines to identify and develop teaching practices and contextual resources that support students' agency construction during their studies.

\section{Conceptualising agency in the higher education context}

The literature on agency has discipline-specific emphases due to different epistemological and ontological roots as well as contexts. Educational constructions of agency have been criticised for focusing either on individual aspects of learning or on the social context (Kahn, Qualter, and Young 2012) and for failing to fully address agency as an interrelationship between the individual and his/her environment (Billet 2008; Hitlin and Elder 2007). In constructing a conceptual template and an empirical tool for examining agency in a higher education context, we drew mainly from research on agency from the perspectives of social sciences, psychology and educational sciences, including work-related learning studies.

In the social sciences, discussions on agency focus on issues such as the impact of societal structures on individuals' opportunities for active participation and the extent to which individuals can influence their own lives (e.g. Berger and Luckmann 1994). Agency is seen to be constructed in relation to power and individuals' sense of it in social relations (see Foucault 1975). Giddens (1984; see also Eteläpelto et al. 2013), for instance, emphasises individuals' intentional and conscious action as well as their capacity to use power to influence the course of social events. Archer (2003) conceptualises agency through the embodied sense of self and internal conversation with one's circumstances. Further, from a philosophical viewpoint, agency is linked to individual and community level manifestations of freedom, democracy and human rights and meaningful causality based on the maintenance of subjectivity with the internalised feeling of power ( $\mathrm{Ci}$ 2011). In sum, these conceptualisations of agency emphasise individuals' capability to engage in intentional, self- 
defined, meaningful and autonomous action which is constrained by power relations and structural, contextual factors.

In research conducted within the framework of social-cognitive psychology, agency is linked to individuals' self-processes, such as conscious intentionality, self-reflection and selfregulation (see Bandura 1989, 2006). Bandura (1986) sees agency as inherently interactional, in that, individuals actively constitute beliefs about their capabilities to have control over events that influence their lives. Personal agency is constructed as a reciprocal interplay of intrapersonal, behavioural and environmental determinants, and self-efficacy beliefs are seen as the core mechanisms influencing action through cognitive, motivational and affective intervening processes (Bandura 1989, 2006). Strong beliefs of efficacy - an individual's beliefs about the extent to which she/he possesses the means to gain certain goals (e.g. Malmberg \& Hagger 2009) - promote well-being, motivation and effort devotion (see Bandura 1989) and a sense of agency. A distinction has been proposed (e.g. Schunk and Zimmerman 2012) between two types of expectancies about future action or learning: competence and control beliefs. Competence beliefs refer to students' self-evaluated perceptions of their knowledge, skills and strategies against the demands of the task whereas control beliefs refer to students' perceptions of the likelihood of achieving desired outcomes under certain circumstances. Motivational theories, such as self-determination theory (Ryan and Deci 2000, 2009), involve assumptions closely related to agency in their claim that intrinsic motivation is maintained when individuals experience the choice to act in the absence of external pressure.

In the context of education, discussion about the concept of agency has been scant. The idea of agency has been seen to date back to the era of the Enlightenment with an emphasis on fostering autonomous action through education (Biesta and Tedder 2007). In line with this emphasis, theories of learning and adult education have included references to concepts akin to agency since the 1980 s, even though the concept has not always been stated explicitly (see Biesta and Tedder 2007; Eteläpelto et al. 2013). These concepts have included empowerment and emancipation as facilitators for individual growth (e.g. Mezirov 1981) and empowering whole communities in developing their life circumstances (Freire 1970). Along with coming of constructivist theories of learning, students' agentic role was seen to be manifested specifically in the act of the construction and reorganisation of knowledge (see Eteläpelto et al. 2013; Packer and Goicoechea 2000). Activity did not merely mean a student's individual and mental engagement in the task but interaction with others in the co-construction of knowledge (Arvaja et al. 2007; van Boxtel, Van der Linden, and Kanselaar 2000). Later, 
within the sociocultural approach (see Packer and Goicoechea 2000), students' participation in social practices and their growth towards full members of the learning community was seen as critical to learning and the construction of their identities (Lave and Wenger 1991). The evolving patterns of participation are seen to influence students' identities as learners, thus contributing to their ways of taking initiative and responsibility for their learning (Greeno 1997).

The sociocultural approach to understanding agency has been criticised for paying insufficient attention to subjectivity and the personal subject (e.g. Billett 2007; Eteläpelto and Lahti 2008; Vähäsantanen, Saarinen, and Eteläpelto 2009). Consequently, a subject-centred socio-cultural perspective on agency has been proposed (Eteläpelto et al. 2013), which considers individual agency and social context as analytically separate but mutually constitutive and interdependent. This perspective pays attention to the subjectivity of individual participation while acknowledging that subjects' thinking, action and learning are always simultaneously resourced and constrained by factors in their socio-cultural contexts, such as the emotional atmosphere and power relations of participants. In order to understand this complex dynamic, participants' experiences and evaluations of trust, safety and equality and their perceptions of their opportunities to influence their community need to be addressed (Eteläpelto and Lahti 2008; Hökkä, Rasku-Puttonen, and Eteläpelto 2008).

Some scholars (e.g. Biesta and Tedder 2007; Emirbayer and Mische 1998) have stated the need to study agency from the life-course perspective, paying attention to the past, present and future time frames. In research on ageing, agency has been considered from the perspective of adults' lifelong learning and adjustment to life changes (e.g. Jyrkämä 2008). Life-course perspectives of agency have not, however, been specifically addressed in the present conceptualisation and questionnaire tool.

Higher education practices that support collaborative construction of content knowledge do not automatically produce a strong sense of agency unless they allow opportunities to make choices, to influence as well as foster structures for equal participation (Eteläpelto et al. 2005; Lipponen and Kumpulainen 2011). In line with the dominant views presented in the literature, we see that by its nature agency is dynamic, contextually situated and relationally constructed. Practicing agency is critically supported by reciprocal and dialogic relations between the teacher and students (Greeno 2006; Lipponen and Kumpulainen 2011), learners' mutual power relations (Eteläpelto et al. 2005), and their capacity to work together (Edwards 2005). 
In this study, the focus is on students' experiences and sense of agency, manifested in their perceptions of personal, relational and situational resources and opportunities for practicing agency, i.e. engaging in knowledge construction that utilises available resources in the temporal relational contexts-for-action (c.f., Emirbayer and Mische 1998). Based on the concepts presented in the existing literature (see Table 1, p. 7), we constructed a heuristic template for understanding student agency in the context of higher education. In the first phase, a literature search was conducted on studies applying the construct of agency in various contexts of learning (including learning at work, professional development or higher education) and nearby disciplines, such as the social sciences and psychology. The literature led us to distinguish clusters of constructs which could be adapted to the students' experiences in higher education contexts (e.g. opportunities for influence, power relations and self-efficacy beliefs).

We argue that agency is related to certain individual resources, such as efficacy and competence beliefs, intrinsic motivation and participation tendencies. However, agency is not construed as an individual's stable feature or existing capacity but, rather, as an individual's action which utilises the resources of the environment (see Biesta and Tedder 2007). Thus, individual factors both manifest and act as sources of agency. However, agency is always relational and context-bound, and especially critical are an individual's experiences and interpretations of relations and opportunities afforded by the environment. In the context of higher education, power relations exist both between the teacher and students and among students. The resources in the context include, but are not restricted to, the teacher's role as an orchestrator who facilitates reciprocity and dialogue among participants and ensures equal opportunities for participation, to make choices and to influence. We recognise that agency manifests itself in action in the interplay with resources that are realised in relationships. In the present study, we define agency in higher education in terms of access to (and use of) resources for purposeful action in study contexts, i.e. as students' experienced or interpreted individual, interactional and contextual resources to engage in intentional and meaningful action and learning.

This study has three aims: (1) to develop a quantitative research tool to assess university students' agency, (2) to provide preliminary reliability and validity evidence for the dimensions of the scale, and (3) to evaluate the feasibility of this tool for helping university teachers to develop their teaching practices to support students' agency construction. 
Table 1: Dimensions of agency in three resource domains

\begin{tabular}{|c|c|c|}
\hline $\begin{array}{l}\text { Resource } \\
\text { Domains }\end{array}$ & $\begin{array}{l}\text { Dimensions of agency and key concepts } \\
\text { in the literature }\end{array}$ & $\begin{array}{l}\text { Manifestations of agency dimensions in a higher } \\
\text { education course-specific study context }\end{array}$ \\
\hline \multirow{4}{*}{$\begin{array}{l}\frac{1}{2} \\
\stackrel{2}{2} \\
\frac{0}{2}\end{array}$} & $\begin{array}{l}\text { Meaning-oriented studying } \\
\text { - Intentionality (e.g. Giddens 1984) } \\
\text { - Wanting (Jyrkämä 2008) } \\
\text { - Intrinsic motivation (Ryan and Deci } \\
\text { 2009) }\end{array}$ & $\begin{array}{l}\text { - Goal to succeed in the course (e.g. utility value) } \\
\text { - Goal to understand the course content } \\
\text { - General motivation and enthusiasm to study in } \\
\text { the course }\end{array}$ \\
\hline & $\begin{array}{l}\text { Self-efficacy } \\
\text { - Beliefs about one's capacity to control } \\
\text { events (e.g. Bandura 1989, 2006) } \\
\text { - Being capable (Jyrkämä 2008) }\end{array}$ & $\begin{array}{l}\text { - Effort to take up challenges } \\
\text { - Self-confidence as a learner }\end{array}$ \\
\hline & $\begin{array}{l}\text { Competence beliefs } \\
\text { - Perceptions of sufficient knowledge } \\
\text { and skills; beliefs about means of } \\
\text { gaining desired goals } \\
\text { (Schunk and Zimmerman 2012) } \\
\text { - Having know-how (Jyrkämä 2008) }\end{array}$ & $\begin{array}{l}\text { - Sense of understanding the course content; } \\
\text { - Feeling competent (cf. competence beliefs) } \\
\text { - Self-evaluation of knowledge and skills to } \\
\text { accomplish desired tasks and learning outcomes } \\
\text { (cf. control beliefs) }\end{array}$ \\
\hline & $\begin{array}{l}\text { Participation activity } \\
\text { - Initiative and engagement in learning } \\
\text { (e.g. Greeno 1997; Packer and } \\
\text { Goicoechea 2000) }\end{array}$ & $\begin{array}{l}\text { - Participation in interactional learning situations } \\
\text { - Taking initiatives in discussion } \\
\text { - Responsibility for completing assigned tasks }\end{array}$ \\
\hline \multirow{3}{*}{ 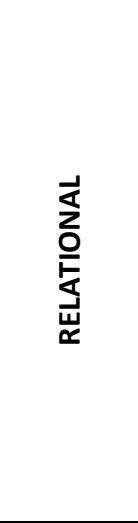 } & $\begin{array}{l}\text { Power relationships } \\
\text { - Equality among students (Eteläpelto } \\
\text { et al. 2005; Eteläpelto and Lahti 2008) } \\
\text { - Reciprocal relation between teacher } \\
\text { and students (c.f. transformative } \\
\text { agency, Lipponen and Kumpulainen } \\
\text { 2011) }\end{array}$ & $\begin{array}{l}\text { - Equal treatment of students by teachers } \\
\text { - Students' equal opportunities to act } \\
\text { - Teacher's authoritative vs. collegial role towards } \\
\text { students } \\
\text { - Non-oppression of students }\end{array}$ \\
\hline & $\begin{array}{l}\text { Peers as resources for learning } \\
\text { - Reciprocal peer support } \\
\text { (c.f. relational agency, Edwards 2005) }\end{array}$ & $\begin{array}{l}\text { - Receiving support from other students } \\
\text { - Providing support to other students }\end{array}$ \\
\hline & $\begin{array}{l}\text { Emotional atmosphere } \\
\text { - Trust and safe environment } \\
\text { (Eteläpelto and Lahti 2008) }\end{array}$ & $\begin{array}{l}\text { - Teachers' approving attitude towards students } \\
\text { - Approachability of the teacher } \\
\text { - Emotional climate in the course }\end{array}$ \\
\hline \multirow{3}{*}{ 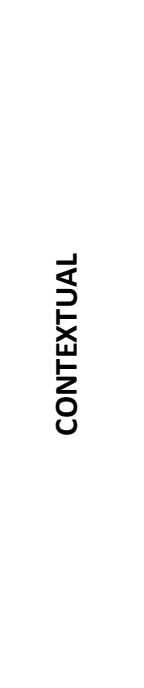 } & $\begin{array}{l}\text { Opportunities for active participation } \\
\text { - Reciprocity in teaching } \\
\text { - Participatory pedagogy } \\
\text { (e.g. Greeno 2006; Lipponen and } \\
\text { Kumpulainen 2011) }\end{array}$ & $\begin{array}{l}\text { - Encouraging students to engage in discussion } \\
\text { and collective meaning-making } \\
\text { - Space for questions and comments }\end{array}$ \\
\hline & $\begin{array}{l}\text { Opportunities to influence } \\
\text { - Support for initiatives (Lipponen and } \\
\text { Kumpulainen 2011) } \\
\text { - Being restricted or having } \\
\text { opportunities to influence (Hökkä et } \\
\text { al. 2008; Jyrkämä 2008) }\end{array}$ & $\begin{array}{l}\text { - Sense of self-direction (or being influenced by } \\
\text { the teacher) in the course } \\
\text { - Opportunities to influence the course progress } \\
\text { - Opportunities to influence one's own studying } \\
\text { - Respecting students' views by course teacher }\end{array}$ \\
\hline & $\begin{array}{l}\text { Opportunities to make choices } \\
\text { - Being restricted or having } \\
\text { opportunities to make choices } \\
\text { (Jyrkämä 2008) } \\
\text { - Absence of external pressure (Ryan } \\
\text { and Deci 2000) }\end{array}$ & $\begin{array}{l}\text { - Choices between various working methods } \\
\text { - Opportunities to make choices with respect to } \\
\text { one's own needs as a learner in the course }\end{array}$ \\
\hline
\end{tabular}




\section{Method}

\section{Participants}

The participants consisted of 239 Finnish university students (142 women; 96 men; missing data for one participant) representing various disciplines: natural sciences (e.g. biological and environmental science), humanities (e.g. history), education (e.g. teacher education), economics (e.g. management and leadership), psychology (e.g. psychological methodology), and sport and health sciences (e.g. sport pedagogy). The data were collected as part of a project involving a multidisciplinary network within the university which was aimed at increasing interactive pedagogy. The agency questionnaires were given to students from ten courses whose teachers participated in the network. The median number of respondents in the courses was 15.00 ( $\mathrm{SD}=32.6$, range 6-116). The participants' mean age was 24.20 years $(S D$ $=6.77$, range 19-58). They had completed a median number of 60.00 credits at the university ( $S D=88.46$; range 2-445; there was missing data on this variable for 19 participants). The number of credits completed was recoded into three categories: $1=1-55$ credits (first year of study: $47.3 \%$ of participants); $2=56-180$ credits (intermediate stage of studies: $36.4 \%$ of participants); $3=181$ credits or more (stage beyond the BA level: $16.3 \%$ of participants).

\section{Instrument construction}

The Agency of University Students Scale (AUS) items were original questions developed by the authors to assess student agency from the perspective of the respondents themselves. At the pilot phase, a different sample of students was asked to fill out the questionnaire, which included two sets of ratings: 42 items asking students to rate their agency experiences in the specified course and 17 items asking students to rate their agency experiences with respect to their university studies in general. In the present study, only data concerning the first set of items, which tapped course-specific agency, will be analysed and reported.

As with the development of any new scale, there was a need to modify the questionnaire developed in the pilot phase. Following the exploratory factor analysis of the structure of the pilot version of the scale, three types of changes were made. First, four items with low factor loadings, or items which were loaded on two factors, in the EFA were omitted from the scale. Second, 13 items were added to the instrument to provide more depth to some areas or to extend an area that had been captured with only one or two items. These areas included, in particular, domains of peer support, participation activity and opportunities to influence. Third, eight items were added to the course-specific set of ratings which had previously only 
been asked with reference to university studies in general (e.g. "I feel that my view and opinions are taken into account in my department" was changed into "I feel that my view and opinions are taken into account in this course"). Finally, marginal language changes were made to 10 items (e.g. clarification of terms).

The final version of the AUS, which was administered to the present sample of 239 students, contained 59 items at the level of a specific course. Their aim was to capture three domains of agency resources (see Table 1): 22 items were intended to tap individual resources (e.g. dimensions of motivation, self-efficacy, competence beliefs, participation tendency); 19 items were intended to measure relational resources (e.g. dimensions of power relations, peer support, emotional atmosphere); and 18 items were intended to assess the contextual resources of agency (e.g. dimensions of opportunities to influence, for making choices and for participation).

Each dimension comprised three to seven items rated using a five-point Likert scale $(1=$ fully disagree, 2 = partly disagree, $3=$ neither agree nor disagree, $4=$ partly agree and $5=$ fully agree). Examples of the items include: 'I asked questions or commented actively in this course', 'This course was not especially inspiring because I do not know whether it is useful for me'. All items were coded, and reversed items were recoded so that higher scores indicated higher levels of agency. Participants were also asked to report their gender, age and the number of credits completed.

\section{Data collection procedure}

The questionnaire was administered to all participating students during the final weeks of the course or immediately after the course. The lecturer was asked to allow some time during the lesson for students to fill in the questionnaire, and the researcher administered the questionnaire. The students could answer the questionnaire anonymously, or they could voluntarily provide their name on the last page if they allowed their responses to be linked to their course grades. They were informed that this information was requested for further analyses that may later be conducted over the course of their study programme. The data collection protocol took a maximum of 30 minutes when administered in the lesson using a pen and paper format (in one of the courses, an alternative computer format was used).

\section{Data analysis steps}

During the very first step, preliminary analyses of the factor structure of the scale were carried out with exploratory factor analyses using maximum likelihood with Kaiser normalisation as 
the rotation method in the SPSS 19 context. EFA was used to isolate the variables that did not measure the dimensions well. Based on our theoretical assumptions of the dimensions of student agency (see Table 1), we expected to identify either a solution with 9 or 10 factors. The model with 10 forced factors provided a solution in which all except for one factor contained a set of cohesive items with high loadings on the respective factor only. The dimension which was not successfully captured in the EFA was Opportunities to influence, but some of the items intended to capture this dimension were retained for the following analyses.

In the next step, confirmatory factor analyses (CFAs) were conducted on the same data using the Mplus statistical package (version 7; Muthén and Muthén 1998-2012) and applying the standard Missing At Random (MAR) approach. The parameters of the models were estimated using the Full Information Maximum Likelihood (FIML) estimation with nonnormality robust standard errors (MLR estimator). The chi-square test $\left(\chi^{2}\right)$, the Comparative Fit Index $(C F I)$, the Tucker-Lewis Index $(T L I)$, the root mean square error of approximation (RMSEA), and the Standardized Root Mean Square Residual (SRMR) were used as indices to evaluate the goodness of fit of the estimated model.

Finally, we examined potential gender differences, and correlations between the AUS scales and students' age and the number of credits.

\section{Results}

\section{Confirmatory factor analysis}

The CFA first indicated a poor fit for the expected ten-factor model $(\mathrm{CFI}=.84$; $\mathrm{TLI}=.83$ ) because of some items with low loadings. Subsequently, four items were omitted due to loadings below .32 on any of the factors, and one item was omitted because its content was not consistent with other items on the respective factor. After these changes, the model fit was acceptable: $\chi^{2}(1322 ; \mathrm{n}=239)=2127.84, p<.001 ; C F I=0.88, T L I=0.86, R M S E A=0.05$, $S R M R=0.07$. The factor loadings of the final CFA were based on 54 items, and the means and standard deviations of the 10 factors are presented in Table 2 . 
Table 2: Factor loadings, factor means and standard deviations based on the final confirmatory factor analysis (CFA)

\begin{tabular}{|c|c|c|c|c|c|c|c|c|c|c|}
\hline \multirow[b]{2}{*}{ Abbreviated items in the order of factors and their loadings } & \multicolumn{10}{|c|}{ CFA factor loadings } \\
\hline & F1 & $\mathrm{F} 2$ & F3 & F4 & F5 & F6 & F7 & F8 & F9 & F10 \\
\hline \multicolumn{11}{|l|}{ Opportunities to make choices } \\
\hline 1. No possibility to choose between various ways of completing the course. ${ }^{\text {a }}$ & .927 & & & & & & & & & \\
\hline 2. Possibility to choose the way to complete the course. & .787 & & & & & & & & & \\
\hline 3. Possibility to take a stand on working methods used in the course. & .484 & & & & & & & & & \\
\hline \multicolumn{11}{|l|}{ Equal treatment } \\
\hline 4. Equality among students. & & .856 & & & & & & & & \\
\hline 5. Other students have a stronger influence on the course. ${ }^{a}$ & & .649 & & & & & & & & \\
\hline 6. Equal treatment of students by teachers. & & .644 & & & & & & & & \\
\hline \multicolumn{11}{|l|}{ Participation activity } \\
\hline 7. Asking questions and making comments in the course. & & & .842 & & & & & & & \\
\hline 8. Expressing opinions in the course. & & & .804 & & & & & & & \\
\hline 9. Taking responsibility by being an active participant. & & & .791 & & & & & & & \\
\hline 10. Enjoyment in taking initiatives and collaborating in the course. & & & .785 & & & & & & & \\
\hline 11. Possibility to express thoughts and views without being ridiculed. & & & .675 & & & & & & & \\
\hline 12. Ease of participation in discussions. & & & .695 & & & & & & & \\
\hline 13. Difficulties participating in discussions. ${ }^{a}$ & & & .660 & & & & & & & \\
\hline 14. Willingness to participate even when having other things to do. & & & .643 & & & & & & & \\
\hline 15. Courage to challenge matters presented in the course. & & & .539 & & & & & & & \\
\hline \multicolumn{11}{|l|}{ Interest and motivation } \\
\hline 16. The course was not inspiring. ${ }^{\text {a }}$ & & & & .827 & & & & & & \\
\hline 17. High motivation to study in the course. & & & & .822 & & & & & & \\
\hline 18. The course was not inspiring because of unclear utility value. ${ }^{a}$ & & & & .800 & & & & & & \\
\hline 19. The contents of the course were interesting. & & & & .709 & & & & & & \\
\hline 20. Desire to succeed in the course. & & & & 692 & & & & & & \\
\hline 21. Desire to learn in order to understand. & & & & 634 & & & & & & \\
\hline 22. Maintaining persistence in the face of the high effort demanded. & & & & .461 & & & & & & \\
\hline
\end{tabular}


Table 2. continued

\begin{tabular}{|c|c|c|c|c|c|c|c|c|c|c|}
\hline \multirow[b]{2}{*}{ Items } & \multicolumn{10}{|c|}{ CFA factor loadings } \\
\hline & F1 & $\mathrm{F} 2$ & F3 & F4 & F5 & F6 & F7 & F8 & F9 & F10 \\
\hline \multicolumn{11}{|l|}{ Self-efficacy } \\
\hline 23. Belief in one's ability to succeed in the course. & & & & & .809 & & & & & \\
\hline 24. Belief in succeeding even in the most challenging tasks. & & & & & .802 & & & & & \\
\hline 25 . Belief in successfully completing the course. & & & & & .784 & & & & & \\
\hline 26. Belief in attaining personal goals set for the course. & & & & & .683 & & & & & \\
\hline 27. Confidence in oneself as a learner in spite of challenges. & & & & & .656 & & & & & \\
\hline \multicolumn{11}{|l|}{ Competence beliefs } \\
\hline 28. Understanding of the course contents. & & & & & & .770 & & & & \\
\hline 29. Sufficient basis for participation in discussions in the course. & & & & & & .760 & & & & \\
\hline 30. Understanding of the constructs presented in the course. & & & & & & .751 & & & & \\
\hline 31. Experiencing course contents as too challenging. ${ }^{a}$ & & & & & & .706 & & & & \\
\hline 32. Lacking basic knowledge for understanding the course contents. ${ }^{a}$ & & & & & & .692 & & & & \\
\hline 33. Experience of a need for revision of basic concepts prior to the course. ${ }^{a}$ & & & & & & .671 & & & & \\
\hline 34. Course demands have not been excessive. & & & & & & .573 & & & & \\
\hline \multicolumn{11}{|l|}{ Teacher support } \\
\hline 35. Belittling of students by teachers. ${ }^{a}$ & & & & & & & .753 & & & \\
\hline 36. Teachers' friendly attitude towards students. & & & & & & & .719 & & & \\
\hline 37. Experience of being oppressed as a student. ${ }^{a}$ & & & & & & & .704 & & & \\
\hline 38. Teachers' contemptuous attitude towards students ${ }^{\text {a }}$ & & & & & & & .683 & & & \\
\hline 39. Not enough room for discussion given by teachers. ${ }^{\text {a }}$ & & & & & & & .474 & & & \\
\hline \multicolumn{11}{|l|}{ Peer support } \\
\hline 40. Experiencing other students as resources for learning. & & & & & & & & .751 & & \\
\hline 41. Providing support for other students in challenging study tasks. & & & & & & & & .745 & & \\
\hline 42. Asking for help from other students when needed. & & & & & & & & .663 & & \\
\hline
\end{tabular}


Table 2. continued

\begin{tabular}{|c|c|c|c|c|c|c|c|c|c|c|}
\hline \multirow[b]{2}{*}{ Items } & \multicolumn{10}{|c|}{ CFA factor loadings } \\
\hline & $\mathrm{F} 1$ & $\mathrm{~F} 2$ & F3 & F4 & F5 & F6 & F7 & F8 & F9 & F10 \\
\hline \multicolumn{11}{|l|}{ Trust } \\
\hline 43. Experience of being welcome in the course. & & & & & & & & & .738 & \\
\hline 44. Approachability of the teachers. & & & & & & & & & .735 & \\
\hline 45. Supportive course climate. & & & & & & & & & .715 & \\
\hline 46. Experience of being able to trust teachers. & & & & & & & & & .704 & \\
\hline 47. Encouraging students to participate in discussions. & & & & & & & & & .569 & \\
\hline 48. Experience of teachers' interest in students' viewpoints & & & & & & & & & .548 & \\
\hline 49. Possibility to be oneself in the course. & & & & & & & & & .544 & \\
\hline \multicolumn{11}{|l|}{ Opportunities to influence } \\
\hline 50. Student viewpoints and opinions were taken into account. & & & & & & & & & & .762 \\
\hline 51. Student viewpoints were listened to. & & & & & & & & & & .741 \\
\hline 52. Experience of having to perform according to external instructions. ${ }^{a}$ & & & & & & & & & & .600 \\
\hline 53. Possibility to choose contents that one finds interesting. & & & & & & & & & & .494 \\
\hline 54. No possibility to influence the course contents. ${ }^{a}$ & & & & & & & & & & .406 \\
\hline Mean & 3.14 & 4.12 & 2.92 & 3.93 & 4.00 & 3.90 & 4.40 & 3.10 & 4.10 & 3.00 \\
\hline$S D$ & 1.14 & 0.78 & 0.93 & 0.71 & 0.70 & 0.71 & 0.64 & 0.98 & 0.61 & 0.78 \\
\hline
\end{tabular}

Note. For better readability, factor loadings less than .32 are not listed. ${ }^{a}$ Reversed-coded item. 
In the CFA, which used the final scale of 54 items, the following 10 factors emerged (reliability coefficients shown in parentheses): Interest and motivation ( 7 items; $\alpha=.87$ ), Selfefficacy ( 5 items; $\alpha=.87$ ), Competence beliefs ( 7 items; $\alpha=.87$ ), Participation activity (9 items; $\alpha=.91$ ), Equal treatment (3 items; $\alpha=.74$ ), Teacher support (5 items; $\alpha=.80$ ), Peer support ( 3 items; $\alpha=.77$ ), Trust (7 items; $\alpha=.84$ ), Opportunities to influence (4 items; $\alpha=$ .76) and Opportunities to make choices ( 3 items; $\alpha=.78$ ). These reliability coefficients indicate moderate to high reliabilities for each scale. Table 3 displays Pearson correlations between the composites representing the 10 factors. In this table, the dimensions are arranged along the three theoretically derived domains representing sources of agency: individual, relational and contextual resources. The correlations between the 10 factors ranged between .01 and .68. The factor of Trust correlated highly with all other factors except for Opportunities to make choices. Self-efficacy correlated particularly highly with three other factors representing the domain of individual resources of agency. Peer support was highly correlated with Participation activity while Teacher support was highly correlated with Trust and Equal treatment. Opportunities to make choices was only weakly correlated with other factors.

Table 3: Correlations between factors

\begin{tabular}{|c|c|c|c|c|c|c|c|c|c|}
\hline Factors & $\begin{array}{c}1 \\
(\mathrm{IM})\end{array}$ & $\begin{array}{c}2 \\
(\mathrm{SE})\end{array}$ & $\begin{array}{c}3 \\
(\mathrm{CB})\end{array}$ & $\begin{array}{c}4 \\
(\mathrm{PA})\end{array}$ & $\begin{array}{c}5 \\
(\mathrm{EQ})\end{array}$ & $\begin{array}{c}6 \\
(\mathrm{TS})\end{array}$ & $\begin{array}{c}7 \\
\text { (PS) }\end{array}$ & $\begin{array}{c}8 \\
\text { (TR) }\end{array}$ & $\begin{array}{c}9 \\
(\mathrm{OI})\end{array}$ \\
\hline \multicolumn{10}{|l|}{ Individual resources } \\
\hline $\begin{array}{l}\text { 1. Interest and } \\
\text { motivation (IM) }\end{array}$ & - & & & & & . & & & \\
\hline 2. Self-efficacy (SE) & $.58 * * *$ & - & & & & & & & \\
\hline $\begin{array}{l}\text { 3. Competence } \\
\text { beliefs (CB) }\end{array}$ & $.47 * * *$ & $.68 * * *$ & - & & & & & & \\
\hline $\begin{array}{l}\text { 4. Participation } \\
\text { activity (PA) }\end{array}$ & $.48 * * *$ & $.58 * * *$ & $.49 * * *$ & - & & & & & \\
\hline \multicolumn{10}{|l|}{ Relational resources } \\
\hline $\begin{array}{l}\text { 5. Equal treatment } \\
\text { (EQ) }\end{array}$ & $.41 * * *$ & $.48 * * *$ & $.45 * * *$ & $.41 * * *$ & - & & . & & \\
\hline $\begin{array}{l}\text { 6. Teacher support } \\
\text { (TS) }\end{array}$ & $48 * * *$ & $.36^{* * *}$ & $.30 * * *$ & $.26^{* * *}$ & $.54 * * *$ & - & & & \\
\hline 7. Peer support (PS) & $.34 * * *$ & $.45^{* * *}$ & $.26^{* * *}$ & $.68^{* * *}$ & $24 * * *$ & $.21^{* *}$ & - & & \\
\hline 8. Trust (TR) & $.56^{* * *}$ & $.57 * * *$ & $.40 * * *$ & $.59 * * *$ & $.61 * * *$ & $.66^{* * *}$ & $.52 * * *$ & - & \\
\hline Contextual resources & & & & & & & & & \\
\hline $\begin{array}{l}\text { 9. Opportunities to } \\
\text { influence (OI) } \\
\text { 10. Opportunities to }\end{array}$ & $.40^{* * *}$ & $.45 * * *$ & $.23 * * *$ & $.56^{* * *}$ & $.24 * * *$ & $.43 * * *$ & $.51 * * *$ & $.57 * * *$ & - \\
\hline make choices (OC) & -.01 & -.11 & $-.21 * *$ & $-.26 * * *$ & -.05 & .12 & $-.19 * *$ & -.03 & .08 \\
\hline
\end{tabular}

Note. $x x x=p<.001 ; x x=p<, 01$ 
We examined gender differences in the AUS factors using the t-test. Significant gender differences emerged only for Interest and motivation $(t(236)=2.72, p=.007)$, indicating that female students $(M=4.03, S D=.68)$ reported higher levels of interest and motivation in the course than their male counterparts $(M=3.78, S D=.72)$. Next, a one-way analysis of variance was carried out to examine whether students' agency ratings varied according to the number of credits completed. The ANOVA showed differences between students with different credit totals in Participation activity $(F(219)=6.78, p=.001)$ : the univariate followup comparisons (using Bonferroni) indicated that those who had completed more than 180 credit points reported participating more actively in their study course $(M=3.32, S D=1.00)$ compared to those who had completed less than 55 credits $(M=2.70, S D=.82)$. Furthermore, the results showed differences between the students with different credits totals in Opportunities to influence $(F(219)=4.65, p=.01)$ : Students who had more than 180 credit points $(M=3.38, S D=.98)$ perceived having more opportunities to influence in their course than students with intermediate credits $(M=2.96, S D=.78)$ and those with the least credits $(M=2.95, S D=.66)$. However, surprisingly, students who had completed 56-180 credits $(M$ $=2.83, S D=1.27$ ) reported lower opportunities to make choices in the course compared to those students with fewer credits $(M=3.36, S D=1.03)$ and those who had more credits $(M=$ $3.25, S D=1.10 ; F(218)=4.96, p=.008)$.

Finally, using correlation analyses (Spearman's rho), we examined whether students' age was associated with factors. The results showed that the older the students were the more they felt peer support during the course $(r=.15, p=.02)$. No other significant associations between age and factors were found.

\section{Discussion}

Developing tools to identify the factors that support or constrain students' agency is pivotal in order to improve higher education teaching practices and respond to the demands of lifelong learning (e.g. Barnett 2009; Case 2013; Su 2011) and professional work (see Eteläpelto et al. 2014). No previous attempts have been made to study student agency with quantitative tools. The questionnaire developed in this study, the Agency of University Students Scale (AUS), aims to encompass the theoretical structure of agency in higher education in a holistic fashion by incorporating multiple dimensions of individual, relational and contextual sources of agency instead of single dimensions. The validation process consisting of EFA and CFA confirmed that a ten-factor structure of the scale provides an acceptable conceptual basis for capturing the resources of agency among university students. 
Based on our theoretical conceptualisation, we assume that the following factors represent individual resources of agency: Interest and motivation, Competence beliefs, Self-efficacy, and Participation activity. The factor of Participation activity was, however, twofold and captured both items indicating an individual's activity of participation (e.g. asking questions, expressing opinions) and the contextual opportunities to participate afforded by the course (e.g. ease of participation). Four of the factors - Equal treatment, Teacher support, Peer support and Trust - are assumed to tap into the experienced interaction climate and relations with others in the course. Finally, two factors are construed as representing contextual support for agency: the factor of Opportunities to influence refers to having a say about the contents or teaching and learning methods used in the course, and that of Opportunities to make choices concerns having options to complete the course.

Cronbach's alphas varied respectively from .74 to .91 for each factor, indicating good internal consistency for the factors. However, correlations between the factors were mostly high, and they were not restricted to the factors within the assumed domains. This result supports our theoretical assumption that the various domains of agency are intertwined. Experiences of trust in learning situations seem to play a strong facilitating role in relation to agency because particularly high correlations emerged between the factor of trust and most of the other factors. Moreover, the analyses comparing the students' agency with the credits from completed courses indicated that students in the final stage of their studies reported their highest participation activity and opportunities to influence whereas students in the middle stage of their studies experienced lower opportunities to make choices compared to both students at the beginning and advanced stages of their studies. It can be speculated that after the BA stage, students may participate in more autonomous formats of study than those attending introductory courses. The advanced stage of studies both requires and provides more independent paths and challenges, e.g. through thesis projects and apprentices. Conversely, in the early stages of university studies, students may need additional support to practice active agency, especially if their high school learning context did not afford independence and self-regulative incentives. In addition, older students reported higher peer support than their younger counterparts. The finding concerning higher education experiences of peer support among older students may be associated with these students' greater ability and confidence regarding the use of collective resources available in the student community and sharing their experiences of work life and other contexts. We found that female students reported higher levels of interest and motivation than male students, but this finding needs to 
be interpreted with caution because it may be due to an interaction between gender and the study course.

\section{Limitations and suggestions for future research}

In the present study, we restricted the scale construction to students' self-assessment of agency in the setting of a specific course. The scale itself has some limitations, and there is a need to develop it further. The assessment of contextual resources, especially with developing more detailed items measuring participation and opportunities to make choices, are needed. In the present scale, Opportunities to make choices focused on options to complete the course. In the further development of the scale, items capturing opportunities in the entire pedagogical process, from making choices between various contents to ways of assessment, could be asked. Opportunities for participation did not constitute a separate factor in the present scale but these contents loaded onto the participation activity factor which emphasised more individual tendencies of participation than contextual opportunities or obstacles.

Because experiences of agency are dynamic and context-bound in nature, future studies should consider the extent to which the course context facilitated it. For instance, information on the variety of learning formats utilised by the teacher and their interactive nature (e.g. group work, collaborative assignments, polls, peer tutoring) would be interesting to analyse as a possible contributing factor in students' experiences of agency. A student may have perceived the resources of agency as non-supportive of independent choices, thus, not having ample room and incentive for subjective action, but a peer may have viewed the same relational and contextual resources as supportive of active participation and equal exchange of ideas (e.g. due to experiences of trust among the participants or between the teacher and the students). Thus, an analysis of students' experiences of agency across different courses and the variance of students' agency perceptions within the same course would be interesting.

Future studies on students' perceptions of agency within other courses offered in their subject major would provide important information on the pedagogical development of study programmes. It would also be important to conduct a longitudinal study by asking the same students to assess their agency at various phases of their university studies. In this way, we would better understand the construction of agency and possible casual mechanisms.

Finally, it is important to recognise the limitations concerning the use of a quantitative method to investigate a phenomenon that is personal, subjective and experimental as well as dynamic and contextual in nature. First, the interpretation of the results must be done with 
caution. Contextual knowledge about the intended pedagogy (including e.g. instructional methods) would be a useful and important addition to the use of the scale. Second, the questionnaire method provides information on the agency profiles of students in the courses as well as potential differences between the courses in the prevailing views. In the future, a mixed methods design utilising both quantitative and qualitative approaches would be helpful to deepen the understanding of the students' experiences.

\section{Practical implications}

This scale can be used as a tool to develop university teaching. First, the scale can give teachers course-specific knowledge about students' agency. With this kind of knowledge, teachers can recognise the sources of low levels of agency and plan pedagogical implementations for fostering agency building during their courses. In pedagogical planning, it would be beneficial to conduct a profile analysis by first examining which of the dimensions were assessed as low and how general the view was among the students in the course. Using the ratings as feedback, the teacher can discuss the views with the students in the course and re-consider the pedagogical choices, e.g. by finding new ways to instil interest in the learning contents (meaning-oriented studying), organising reciprocal learning situations between the students or lowering the threshold for active participation. Moreover, the scale might be used as part of personal study plans by implementing the self-assessment of agency at various stages of study to obtain information on agency construction in the long run. In relation to general academic assessment in higher education, the scale could provide a tool for the evaluation of teaching quality and the effectiveness of educational programmes. For example, the sharing of best practices is easier when the scale is implemented at a universitywide level. In addition, the results of the scale could be utilised to identify problems relating to bottlenecks that hinder progress or lead to drop out. The scale is intended for shared pedagogical discussion and concerted intervention actions among teachers and not for the top-down control of individual teachers or screening. Reflecting on the results is thus an optimal part of ongoing development work in which the goal is to empower both students and teachers in a safe and trustful environment.

\section{Acknowledgements}

The authors express their gratitude to the University of Jyväskylä for supporting the development of teaching in higher education. 


\section{References}

Archer, M. 2003. Structure, Agency and the Internal Conversation. Cambridge: Cambridge University Press.

Arvaja, M., H. Salovaara, P. Häkkinen, and S. Järvelä. 2007. "Combining Individual and Group-Level Perspectives for Studying Collaborative Knowledge Construction in Context." Learning and Instruction 17 (4): 448-459.

Bandura, A. 1986. Social Foundations of Thought and Action: A Social Cognitive Theory. Englewood Cliffs, NJ: Prentice-Hall.

Bandura, A. 1989. "The Human Agency in Social Cognitive Theory." American Psychologists 44 (9): 1175-1184.

Bandura, A. 2006. "Toward a Psychology of Human Agency." Perspectives on Psychological Science 1 (2): 164-180.

Barnett, R. 2009. "Knowing and Becoming in the Higher Education Curriculum." Studies in Higher Education 34 (4): 429-440.

Berger, P., and T. Luckmann 1994 Todellisuuden sosiaalinen rakentuminen: tiedonsosiologinen tutkielma. [The Social Construction of Reality: A Treatise in the Sociology of Knowledge, 1966] Translated by V. Raiskila. Helsinki: Gaudeamus.

Biesta, G., and M. Tedder. 2007. "Agency and Learning in the Lifecourse: Towards an Ecological Perspective." Studies in the Education of Adults 39 (2): 132-149.

Billett, S. 2007. "Exercising Self through Working Life: Learning, Work and Identity." In Identities at Work, edited by A. Brown, S. Kirpal, and F. Rauner, 183-210. Dordrecht: Springer Science.

Billett, S. 2008. "Learning Throughout Working Life: A Relational Interdependence between Personal and Social Agency.” British Journal of Education Studies 55 (1): 39-58.

Bonneville-Roussy, A., R.J. Vallerand, and T. Bouffard. 2013. "The Roles of Autonomy, Support and Harmonious and Obsessive Passions in Educational Persistence." Learning and Individual Differences 24: 22-31.

Busse, V. 2013. "Why Do First-Year Students of German Lose Motivation during Their First Year at University?" Studies in Higher Education 38 (7): 951-971.

Case, J. M. 2013. Researching Student Learning in Higher Education: A Social Realist Approach. Society for Research into Higher Education. London: Routledge.

Ci, J. 2011. "Evaluating Agency: A Fundamental Question for Social and Political Philosophy." Metaphilosophy 42 (3): 261-281. 
Cornelius-White, J. 2007. "Learner-Centered Teacher-Student Relationships Are Effective: A Meta-Analysis." Review of Educational Research 77 (1): 113-143.

Edwards, A. 2005. "Relational Agency: Learning To Be a Resourceful Practitioner." International Journal of Educational Research 43 (3): 168-182.

Elen, J., G. Clarebout, R. Leonard, and J. Lowyck. 2007. "Student-Centred and TeacherCentred Learning Environments: What Students Think." Teaching in Higher Education 12 (1): 105-117.

Emirbayer, M., and A. Mische. 1998. "What Is Agency?” American Journal of Sociology 103 (4): 962-1023.

Eteläpelto. A., and J. Lahti. 2008. "The Resources and Obstacles of Creative Collaboration in a Long-Term Learning Community." Thinking Skills and Creativity 3 (3): 226-240.

Eteläpelto, A., K. Littleton, J. Lahti, and S. Wirtanen. 2005. "Students' Accounts of their Participation in an Intensive Long-Term Learning Community." International Journal of Educational Research 43 (3): 183-207.

Eteläpelto, A., K. Vähäsantanen, P. Hökkä, and S. Paloniemi. 2013. "What Is Agency? Conceptualizing Professional Agency at Work." Educational Research Review 10: 4565.

Eteläpelto, A., K. Vähäsantanen, P. Hökkä, and S. Paloniemi. 2014. "Identity and Agency in Professional Learning." In International Handbook of Research of Professional and Practice-Based Learning, edited by S. Billet, C. Harteis, and H. Gruber, 645-670. Dordrecht: Springer.

Foucault, M. 1975. Discipline and Punish: The Birth of the Prison. New York: Random House.

Freire, P. 1970. Pedagogy of the Oppressed. Translated by M. Bergman Ramos. New York: Herder and Herder.

Framework of Qualifications for the European Higher Education Area. 2005. http://www.ond.vlaanderen.be/hogeronderwijs/bologna/documents/.

Giddens, A. 1984. The Constitution of Society. Berkeley: University of California Press.

Greeno, J.G. 1997. "On Claims that Answer the Wrong Question.” Educational Researcher 26 (1): $5-17$.

Greeno, J.G. 2006. "Authoritative, Accountable Positioning and Connected, General Knowing: Progressive Themes in Understanding Transfer." The Journal of the Learning Sciences 15: 537-547. 
Hitlin, S., and G.H. Elder. 2007. "Time, Self and the Curiously Abstract Concept of Agency." Sociological Theory 25 (2): 170-191.

Hökkä, P., H. Rasku-Puttonen, and A. Eteläpelto. 2008. "Teacher Educators' Workplace Learning: The Interdependency between Individual Agency and Social Context.” In Emerging Perspectives in Workplace Learning, edited by S. Billett, C. Harteis, and A. Eteläpelto, 51-66. Rotterdam: Sense Publishers.

Jolanki, O.H. 2009. “Agency in Talk about Old Age and Health.” Journal of Aging Studies 23 (4): $215-226$.

Jyrkämä, J. 2008. Toimijuus, ikääntyminen ja arkielämä - Hahmottelua teoreettismetodologiseksi viitekehykseksi [“Agency, Ageing and Routine - Outlining a Theoretical-Methodological Framework"]. Gerontologia [Gerontology] 4: 190-203.

Kahn, P., A. Qualter, and R. Young. 2012. "Structure and Agency in Learning: A Critical Realist Theory of the Development of Capacity to Reflect on Academic Practice." Higher Education Research \& Development 31 (6): 859-871.

Kylie, V. 2011. “Accounting for Agency.” Children \& Society 25 (5): 347-358.

Lave, J., and E. Wenger. 1991. Situated Learning: Legitimate Peripheral Participation. Cambridge: Cambridge University Press.

Liimakka, S. 2011. "Cartesian and Corporeal Agency: Women's Studies Students' Reflections on Body Experience." Gender and Education 23 (7): 811-823.

Lipponen, L., and K. Kumpulainen. 2011. "Acting as Accountable Authors: Creating Interactional Spaces for Agency Work in Teacher Education." Teaching and Teacher Education 27 (5): 812-819.

Littleton, K., S. Taylor, and A. Eteläpelto. 2012. "Special Issue Introduction: Creativity and Creative Work in Contemporary Working Contexts." Vocations and Learning 5 (1): 1-4.

Malmberg, L.-E., and H. Hagger. 2009. “Changes in Student Teachers' Agency Beliefs during a Teacher Education Year, and Relationships with Observed Classroom Quality, and Day-To-Day Experiences." British Journal of Educational Psychology 79: 667-694.

Mattern, R.A. 2005. “College Students' Goal Orientations and Achievement.” International Journal of Teaching and Learning in Higher Education 17 (1): 27-32.

McCabea, A., and U. O’Connorb. 2014. “Student-Centred Learning: The Role and Responsibility of the Lecturer.” Teaching in Higher Education 19 (4): 350-359.

Mezirov, J. 1981. "A Critical Theory of Adult Learning and Education.” Adult Education 32 (1): $3-24$.

Michelsena, S. 2011. "Humboldt Meets Bologna.” Higher Education Policy 23 (2): 151-172. 
Mikkonen, J., M. Ruohoniemi, and S. Lindblom-Ylänne. 2013. "The Role of Individual Interest and Future Goals during the First Years of University Studies.” Studies in Higher Education 38 (1): 71-86.

Muthén, L.K., and B.O. Muthén. 1998-2012. Mplus User's Guide. 7th ed. Los Angeles, CA: Muthén \& Muthén.

OECD. 2013. “Assessment of Higher Education Learning Outcomes.” AHELO. Feasibility Study Report. Volume 2. Data Analysis and National Experiences. http://www.oecd.org/education/skills-beyond-school/AHELOFSReportVolume2.pdf

Paloniemi, S., and K. Collin. 2012. "Discursive Power and Creativity in Inter-Professional Work." Vocations and Learning 5 (1): 23-40.

Packer, M.J., and J. Goicoechea. 2000. "Sociocultural and Constructivist Theories of Learning: Ontology, Not Just Epistemology.” Educational Psychologist 35 (4): 227-241.

Ryan, R.M., and E.L. Deci. 2000. "Intrinsic and Extrinsic Motivations: Classic Definitions and New Directions." Contemporary Educational Psychology 25: 54-67.

Ryan, R.M., and E.L. Deci. 2009. "Promoting Self-Determined School Engagement: Motivation, Learning, and Well-Being." In Handbook on motivation at school, edited by K. R. Wentzel, and A. Wigfield, 171-196. New York: Routledge.

Santiago, R., T. Carvalho, and R. Relva. 2008. "Research and the Universities' Image." European Journal of Education 43: 495-512.

Schunk, D.H., and B.J. Zimmerman. 2012. "Competence and Control Beliefs: Distinguishing the Means and Ends." In Handbook of Educational Psychology, edited by P.A. Alexander, and P.H. Winne, 349-368. NY: Routledge.

Su, Y-H. 2011. "The Constitution of Agency in Developing Lifelong Learning Ability: The 'Being' Mode.” Higher Education 62: 399-412.

Trede, F., R. Macklin, and D. Bridges. 2012. "Professional Identity Development: A Review of the Higher Education Literature." Studies in Higher Education 37 (3): 365-384.

Tynjälä, P. 2010. "Towards a 3-P Model of Workplace Learning: A Literature Review." Vocation and Learning 6: 11-36.

van Boxtel, C., J. van der Linden, and G. Kanselaar. 2000. "Collaborative Learning Tasks and the Elaboration of Conceptual Knowledge." Learning and Instruction 10: 311-330.

van Dinther, M., Dochy, F., and M. Segers. 2011. "Factor Affecting Students' Self-Efficacy in Higher Education." Educational Research Review 6 (2): 95-108.

Vähäsantanen, K., A. Eteläpelto, and J. Saarinen. 2009. "Creativity and Agency in Negotiating Career Trajectories within Transitional Situations.” Paper presented in the 
Symposium of the Work Research Conference on Understanding Creative Work: SocioCultural Approaches, Tampere, Finland, November 2009.

\section{List of the tables:}

Table 1. Dimensions of agency in three resource domains

Table 2. Factor loadings, factor means, and standard deviations based on the final confirmatory factor analysis (CFA)

Table 3. Correlations between factors 